\title{
SEKTARIANISME DALAM SEJARAH ISLAM
}

\author{
Humaira Azzahra \\ UIN Syarif Hidayatullah Jakarta, Indonesia \\ humaira.az13@mhs.uinjkt.ac.id
}

\begin{abstract}
The presence of sects in Islamic history was initially ridden by political factors. They were born as a political stream that has a share in government power. However, over time, these schools began to stand on the level of aqidah and divinity. Each sect has its own understanding of divine principles, politics, and Islamic values. It cannot be denied that this is a global concern for Muslims because it has the potential to cause division. Among the sects recorded in the history of Islam are the Shia, Khawarij, Murji'ah, Qadariyah, Jabariyah, Mu'tazilah, Asy'Ariyah, and Maturidiyah. The importance of studying sectarianism in the history of Islam is to understand the Islamic patterns that exist in various countries so as to make us have a wiser point of view in seeing diversity in religion.
\end{abstract}

Kata Kunci: sekte, aliran teologi, politik islam, sejarah.

\section{A. Pendahuluan}

Sejarah Islam menunjukkan ada banyak aliran atau sekte yang muncul karena perbedaan perspektif sehingga melahirkan gagasan yang berbeda-beda. Penyebab utama timbulnya aliran-aliran ini adalah upaya untuk melakukan pembaharuan pada aliran yang sebelumnya telah berlaku sejak lama. Adanya pembaharuan ini menghasilkan hal-hal baru terhadap ajaran klasik yang bagi sebagian kelompok mmenjadi sebuah masalah. Disamping itu, ada pula kelompok yang setuju dan mengikutinya. Hal ini kemudian mengakibatkan terbentuknya sebuah ajaran atau aliran baru dalam masyarakat.

Benih-be/nih perpecahan di antara umat Islam ditunggangi oleh faktor politik. ${ }^{1}$ Sejarah mencatat bahwa sebelum jasad Rasulullah dimakamkan, pertentangan di dalam masyarakat Islam telah muncul terutama perihal kandidat pengganti Nabi Muhammad SAW yang akan menempati posisi pemimpin negara. Dalam hal ini, umat Islam terpecah menjadi 2 kelompok dikarenakan perbedaan pandangan satu sama lain. Kelompok pertama meyakini bahwa Nabi tidak meninggalkan wasiat apapun terkait siapa yang berhak menggantikannya setelah wafat. Untuk itu, kelompok ini mengambil sikap bahwa keputusan kepemimpinan selanjutnya harus dengan melibatkan seluruh lapisan rakyat. Rakyat memiliki otoritas penuh untuk menentukan siapa yang akan memimpin mereka selajutnya, terutama setelah Nabi Muhammad tiada. Adapun kelompok lainnya beranggapan bahwa masalah kepemimpinan tidak perlu melibatkan seluruh rakyat. Akan tetapi cukuplah Allah dan Nabi Muhammad yang menentukannya. Disisi lain, mereka juga meyakini bahwa Nabi Muhammad sebelum berpulang ke pangkuan-Nya telah menunjuk

${ }^{1}$ Ahmad Ibrahim Hamur, Shadrat min Tarikh al-Daulah al-Umawiyah fi al-Sharq (Kairo: Daar alTiba'ah al-Muhammadiyah, 1998), 115. 
Ali bin Abi Thalib sebagai penggantinya. ${ }^{2}$

Cuplikan kisah tersebut memberi gambaran awal pada kita munculnya perpecahan masyarakat Islam yang bersumber dari pertentangan pendapat sekelompok umat mengenai kepemimpinan. Masing-masing memiliki pandangan tersendiri mengenai kandidat yang seharusnya menjadi pemimpin umat dan menggantikan posisi Nabi Muhammad yang telah wafat. Seiring dengan berjalannya waktu, perbedaan pandangan ini terus bergulir kepada generasi selanjutnya di kalangan umat Islam yang kemudian berujung pada timbulnya politik sektarian. Tak dapat dihindari, terbentuklah aliran-aliran teologi yang mewarnai sejarah peradaban umat Islam dan berdampak sangat signifikan hingga dimasa sekarang.

Apa yang dimaksud dengan sektarianisme? Bagaimana pengaruhnya dalam kehidupan keagamaan? Bagaimana proses munculnya sekte-sekte keagamaan dalam Islam? Ulasan dari pertanyaan-pertanyaan tersebut menjadi topik utama pembahasan artikel ini.

\section{B. Sektarianisme dan Timur Tengah}

Sektarianisme secara etimologis berasal dari kata sekte, yang memiliki arti suatu kelompok orang yang mempunyai kepercayaan atau pandangan agama yang sama, yang berbeda dari pandangan agama yang lebih lazim diterima oleh para penganut agama tersebut. Ia juga merupakan nama lain dari mazhab. Kata sektarianisme sendiri memiliki beberapa pengertian menurut Kamus Besar Bahasa Indonesia (KBBI). Pertama, yaitu semangat membela suatu sekte atau mazhab, kepercayaan, atau pandangan agama yang berbeda dari pandangan agama yang lebih lazim diterima oleh para penganut agama tersebut. Kedua, berupa aliran dalam politik yang antikomunikasi, reaksioner, amat emosional, tidak kritis, angkuh, dan antidialog. Istilah sektarianisme sering digunakan dalam kajian konflik Timur Tengah yang pada umumnya berakar pada perbedaan pemahaman dalam menjalankan nilai-nilai keislaman.

Telah diketahui bersama bahwa pusat lahirnya agama-agama besar di dunia berasal dari Timur Tengah. Tak hanya menjadi rahim awal, Timur Tengah juga berperan penting sebagai tempat berseminya berbagai sekte atau mazhab keagamaan yang cukup berpengaruh. Berbagai konflik yang terjadi di Timur Tengah tak dapat dilepaskan dari berbagai sekte yang masih eksis di wilayah ini. Untuk itu, dalam melakukan penelusuran terhadap akar permasalahan konflik di Timur Tengah para peneliti akan dihadapkan pada sebuah sentimen keagamaan sekte tertentu. Sektarianisme selalu menjadi topik hangat dalam kajian ketidakstabilan politik Timur Tengah. ${ }^{3}$

Meskipun paham demokrasi telah lama diterapkan dalam sistem pemerintahan, pada prakteknya sejumlah pertikaian akibat sektarianisme masih dapat dijumpai di kawasan ini. Jika menilik kepada sejarah, mencuatnya isu sektarianisme di Timur Tengah justru terjadi saat pembaharuan menuju sistem pemerintahan demokrasi. Masa transisi ini diawali dengan Arab Spring yang terjadi di sebagian besar negara kawasan Timur Tengah. Pada tahun 2010, aksi pembakaran diri oleh Mohamed Bouazizi menjadi awal munculnya

${ }^{2}$ Zainal Abidin, "Syiah dan Sunni dalam Perspektif Pemikiran Islam," Jurnal Hunafa 3, 2 (2006): $117-128$

${ }^{3}$ Sainul Rahman, "Tensi Sektarianisme dan Tantangan Demokrasi di Timur Tengah Pasca Arab Spring: Kasus Tunisia dan Yaman,” Jurnal ICEMS 3, 1 (2019): 112 
gelombang anti-pemerintah yang kemudian terus bergulir berujung pada revolusi Tunisia. Dari Tunisia, aliran protes merambah ke sejumlah negara sekitar seperti Mesir, Libya, Yaman, Bahrain, dan Suriah. Berbagai konflik yang terjadi setelahnya hingga masa sekarang memberi gambaran betapa sektarianisme turut mewarnai perjalanan perpolitikan di kawasan Timur Tengah. ${ }^{4}$

\section{Sejarah Sektarianisme dalam Islam}

Kekuatan politik dan semangat keagamaan muncul sepeninggal Nabi Muhammad SAW. Banyak pertentangan dan perbedaan pandangan di kalangan masyarakat Islam sehingga memicu timbulnya perpecahan antarumat. Hal ini dikarenakan Nabi sama sekali tidak menunjuk seorang pengganti yang akan menduduki posisi jabatannya sebagai kepala negara jika Ia telah tiada. Beberapa kalangan kemudian berpendapat bahwa Nabi memberikan keputusan mengenai kekhalifahan dengan ditunjuk langsung oleh rakyat.

Pemilihan pemimpin negarapun dipilih melalui musyawarah terbuka dan menghasilkan penetapan Abu Bakar As-Shiddiq sebagai pemimpin negara menggantikan Nabi Muhammad SAW. Di masa-masa setelahnya, pemilihan pemimpin dilakukan dengan menggunakan jalur yang berbeda-beda. Umar bin Khattab ditetapkan sebegai khalifah atas penunjukkan pemimpin sebelumnya. Adapun Utsman bin Affan resmi menjadi pemimpin setelah disetujui oleh sebuah lembaga masyarakat. Sedangkan Ali bin Abi Thalib diberikan mandat sebagai khalifah setelah melalui persetujuan sebuah pertemuan terbuka. ${ }^{5}$

Konflik sektarianisme dalam Islam diawali oleh peristiwa tahkim (perundingan) pada Perang Shiffin. ${ }^{6}$ Perang Shiffin merupakan perang saudara yang terjadi pada masa sahabat. Gejolak politik yang sangat kuat antara pengikut Ali bin Abi Thalib dan lawannya, Muawiyah bin Abi Sufyan, menjadi penyebab timbulnya perang antarumat Islam ini. Ali bin Abi Thalib sebagai khalifah harus menghadapi pemberontakan yang diinisiasi oleh Muawiyah bin Abi Sufyan yang pada waktu itu menjabat sebagai Gubernur Syam.

Pada mulanya, Ali telah memberikan alternatif damai untuk menyelesaikan persoalan dengan pihak Muawiyah agar tidak terjadi pertumpahan darah di dalam tubuh kaum muslimin. Namun hal ini ditolak oleh Muawiyah. Berbagai opsi yang kembali Ali tawarkan hanya berujung pada jalan buntu. Muawiyah memang tidak ingin berdamai dengan syarat apapun. Perangpun tak terhindarkan. Di dalam perang yang sedang berkecamuk, Muawiyah hampir mengalami kekalahan karena kondisi pasukannya yang melemah. Tak tinggal diam, salah seorang tangan kanan Muawiyah, Amr Ibn Al-'As, memerintahkan pasukannya mengangkat Al-Qur'an melalui ujung tombak sebagai tanda meminta berdamai. ${ }^{7}$ Pasukan Ali dari golongan Qurra' (ahli Quran) yang melihat hal itu kemudian meminta agar Ali menerima tawaran dari kubu lawan. Dalam keadaan tersebut, Ali terpaksa menghentikan peperangan yang tinggal selangkah lagi ia menangkan.

${ }^{4}$ Azyumardi Azra, Transformasi politik Islam: radikalisme, khilafatisme, dan demokrasi (Jakarta: Prenadamedia Group, 2016), 273.

5 A. Dzujali, Fiqh as-Siyasah: Implementasi Kemaslahatan Umat Islam dalam Rambu-Rambu Syariah (Jakarta: Kencana, 2013), 27-28

${ }^{6}$ Abdul Hakim, "Konflik Sektarian Dan Perkembangan Pemikiran Dalam Islam," SAFINA: Jurnal Pendidikan Agama Islam 1, 1 (2016): 57.

${ }^{7}$ M. Syamruddin Nasution, Arbitrase Menjadi Penyebab Timbulnya Sekte-sekte dalam Islam (Pekan Baru: Yayasan Pusaka Riau, 2011), 82. 
Penghentian peperangan ini diikuti oleh sebuah solusi perdamaian melalui arbitrase. Proses ini memiliki beberapa pola. Pertama, arbitrase dilakukan dengan mengusung sebuah nama yang berperan sebagai arbiter. Arbitrer berfungsi untuk menyelesaikan sengketa kedua pihak yang berseteru. Kedua, arbitrase juga dapat dilakukan dengan beberapa orang sebagai arbiter. Dalam kasus Ali dan Muawiyah, arbitrase yang digunakan mengikuti pola kedua, yaitu melalui dua arbiter. Masing-masing pihak yang berselisih menentukan seorang perwakilannya untuk berkumpul merembukkan permasalahan yang terjadi antara kedua kubu hingga ditemukan solusinya. ${ }^{8}$

Sebagai perwakilan Muawiyah, Amr Ibn Al-'As maju berunding dengan Abu Musa Al-Asy'ari dari pihak Ali. Keduanya kemudian sepakat untuk menjatuhkan kedua pemimpin yang saling bertentangan, yakni Ali dan Muawiyah. Sejarah mencatat kelicikan Amr Ibn Al-'As dalam peristiwa perundingan ini. Abu Musa Al-Asy’ari sebagai yang tertua telah lebih dahulu mengumumkan keputusan menjatuhkan kedua pemuka yang bertentangan di depan khalayak, sedangkan Amr Ibn Al-'As mengumumkan hanya menyetujui penjatuhan Ali sebagaimana yang disampaikan Al-Asy'ari sebelumnya namun menolak penjatuhan Muawiyah. Hal ini tentu sangat merugikan pihak Ali. Muawiyah yang pada awalnya hanya seorang Gubernur yang menentang khalifah dengan arbitrase ini naik menjadi khalifah meskipun secara tidak resmi. Ali-pun menolak menurunkan jabatannya bahkan hingga kematiannya.

Banyak kalangan, baik dari kubu Ali maupun Muawiyah sendiri, tidak sepakat dengan kebijakan yang diambil oleh para pemimpinnya dalam peristiwa ini sehingga memunculkan perpecahan kaum muslimin. Peristiwa tahkim menjadi sejarah lahirnya sekte-sekte dalam Islam. Menurut kacamata politik, terdapat 3 kelompok yang lahir dari peristiwa ini, yaitu (1) Khawarij, ialah bagian dari pendukung Ali yang menganggap bahwa keputusan Ali untuk menerima arbitrase dari Muawiyah adalah tidak tepat. Oleh karena itu, mereka meninggalkan atau memisahkan diri dari barisannya, (2) Syiah, merupakan bagian dari kubu Ali bin Abi Thalib, dan (3) Murjiah, yaitu golongan pendukung Muawiyah. Adanya perselisihan ini menyulut api kegelisahan ditengah masyarakat umum karena hingga saat ini masih terus berlangsung. ${ }^{9}$

Machasin menggarisbawahi tiga aliran teologi Islam yang masyhur hingga saat ini. Mereka adalah Khawarij, Syiah, dan Sunni. Kemunculan tiga aliran ini ditunggangi oleh hawa politik yang saat itu tengah bergejolak. ${ }^{10}$ Memperebutkan kekuasan adalah target utama dari kelompok-kelompok ini. Hal ini dapat dilihat dari sisi perlawanan Khawarij terhadap keputusan Ali bin Abi Thalib yang menerima tahkim. Prinsip yang dikedepankan adalah laa hukma illallah (suatu hukum itu hanyalah milik Allah) ${ }^{11}$.

Berbeda dengan Khawarij, Syiah adalah kelompok tidak sepakat untuk memproklamirkan Abu Bakar sebagai khalifah pengganti Nabi setelah Nabi wafat. Mereka menganggap bahwa Ali telah diwasiatkan oleh Nabi untuk menduduki posisinya. Untuk

8 Ahmad Syalabi, Tarikh al-Islam wa al-Hadharah al-Islamiyah, Juz 1 (Mesir: Maktabah alNahdhah al-Misriyah, 1975), 302.

${ }^{9}$ A. Hasyimi, Sejarah Kebudayaan Islam (Jakarta: Bulan Bintang, 1973), 157.

${ }^{10}$ Machasin, Islam Dinamis Islam Harmonis, Lokalitas, Pluralisme, dan Terorisme (Yogyakarta: LKIS, 2017), 97-98. 1986), 15

${ }^{11}$ Harun Nasution, Teologi Islam: Aliran-Aliran Sejarah Analisa Perbandingan (Jakarta: UI-Press, 
itu, khalifah pertama, kedua dan ketiga dianggap tidak sah. Kelompok Syi'ah tidak mengakui kekhalifahan Abu Bakar Ash-Shiddiq, Umar bin Khattab, dan Utsman bin Affan. Hal ini juga diamini oleh Fatimah, Ali, dan cucu Nabi. Penobatan terhadap khalifah Abu Bakarpun baru dilaksanakan setelah Fatimah wafat. ${ }^{12}$

Adapun kelompok Sunni mempercayai bahwa antara agama dan negara tidak dapat terpisahkan. Menurut anggapan mereka, seorang kepala negara tidak ubahnya sebagai inti dari sebuah pergerakan Islam yang akan menentukan arah kebijakan dan visi umat. Oleh karena itu, kebijakan dan keputusan yang dikeluarkan oleh seorang pemimpin tidak boleh di lawan. Dalam kondisi tertentu malah ketaatan terhadap pimpinan adaalah sebuah keniscayaan. ${ }^{13}$

Munculnya aliran-aliran teologi ini pada awalnya dimotori oleh faktor politik yang menghangat. Namun lambat laun terjadi pergeseran yang tadinya fokus pada kekuasaan berpindah semakin jauh memasuki wilayah aqidah, prinsip, dan kepercayaan. Hal ini berujung pada tataran hakikat muslim dan kafir serta menuduh kelompok tertentu telah melenceng atau masih dalam nilai-nilai keislaman. ${ }^{14}$

\section{Bentuk-Bentuk Sektarianisme}

Sektarianisme memiliki beberapa bentuk sebagai akibat dari gejolak politik didalam masyarakat Islam. Diantara bentuk aliran tersebut adalah sebagai berikut.

\section{Syi'ah}

Syiah adalah sekte politik pertama dalam sejarah Islam. ${ }^{15}$ Kata Syiah berasal dari kata sya'a yang berarti tersiar, menyiarkan, mengisi, mengikuti, dan menemani. ${ }^{16}$ Istilah Syi'ah digunakan untuk penyebutan kelompok yang menyokong Ali bin Abi Thalib dan lebih mengutamakannya dibanding para sahabat Nabi yang lain. ${ }^{17}$ Nabi telah menyandarkan istilah Syiah kepada Ali bin Abi Thalib dan para pengikutnya. Dalam kitab Al-Durr al-Mantsur, Jaluddin as-Suyuthi menuliskan, "Dari Ibnu 'Asakir kemudian dari Jabir bin Abdullah bahwa: Kami sedang bersama Nabi Muhammad saw. Tidak lama kemudian Ali datang. Lalu Nabi Muhammad saw bersabda, "Demi yang jiwaku berada digenggaman-Nya, sesungguhnya ini (Ali) dan Syiahnya benar-benar orang yang menang di hari kiamat". As-Suyuthi kembali mencantumkan dalam kitabnya, "Ibn Abbas berkata: Ketika turun ayat, "Sesungguhnya orang-orang yang beriman dan beramal saleh, mereka itulah sebaik-baik manusia"; Rasulullah saw berkata kepada Ali: mereka adalah engkau dan Syiahmu". ${ }^{18}$

Menurut Syahrastani, Syiah mempercayai bahwa Ali bin Abi Thalib adalah

12 Fahmi Farid Purnama, "Khawarijisme: Pergulatan Politik Sektarian dalam Bingkai Wacana Agama," Jurnal Al-A'raf Pemikiran Islam dan Filsafat 3, 2 (2016): 217.

${ }^{13}$ Philip K. Hitti, History of The Arabs (London: Macmillan Press, 1970), 191.

${ }^{14}$ Harun Nasution, Teologi Islam: Aliran-Aliran Sejarah Analisa Perbandingan, 8.

15 Imam Muhammad Abu Zahrah, Aliran Politik dan Aqidah dalam Islam, terj. Abd. Rahman Dahlan dan Ahmad Qarib (Jakarta: Logos Publishing House, 1996), 34.

16 Ahmad Warson Munawir, Kamus Munawir Arab-Indonesia Terlengkap (Surabaya: Pustaka Progresif, 2007), 756.

17 Abu Hasan Al-Asy’ari, Maqallat al-Islamiyyin wa Ikhtilafu al-Mushallin (Kairo: Maktabah AnNahdhah al-Misriyyah, 1969), 65.

${ }^{18}$ Ahmad Sahidin, "Memahami Sunni dan Syiah: Sejarah, Politik, dan Ikhtilaf," Jurnal Maarif 10,.2 (2015): 36 . 
kandidat yang telah dipilih oleh Nabi dan dipesankan untuk menggantikan posisinya sebagai kepala negara. Syiah juga menganggap bahwa seorang pemimpin harus berasal dari garis nasab keturunan Ali bin Abi Thalib. Bagi yang bukan merupakan keturunan Ali, maka ia tidak bisa menjadi pemimpin suatu negara. ${ }^{19}$ Aliran ini tidak menunjukkan pergerakan apapun pada masa kepemimpinan khalifah Abu Bakar dan Umar. Makar proAli baru mulai merebak pada masa Utsman bin Affan dengan tujuan untuk melengserkan kekuasaannya. Kelompok ini semakin menampakkan diri pada saat munculnya pertikaian antara Ali bin Abi Thalib dengan Muawiyah bin Abi Sufyan yang berujung pada arbitrase.

Jika ditelisik lebih lanjut, sebenarnya secara tidak langsung pandangan kaum Syi'ah tersebut telah tertolak dengan sendirinya. Hal ini disandarkan pada fakta bahwa Ali bin Abi Thalib sendiri mengakui legalitas ketiga khalifah sebelumnya bahkan turut serta dalam membaiat mereka menjadi pemimpin kaum muslimin. Ini menunjukkan secara jelas bahwa Ali secara pribadi tidak menganggap dirinya yang lebih berhak menggantikan Nabi serta membuktikan betapa Ali-pun tidak merasa menerima wasiat Nabi sebagaimana yang digaungkan oleh kelompok Syiah.

\section{Khawarij}

Khawarij menurut bahasa adalah jama' dari isim fail Kharij, artinya sesuatu yang keluar. Dalam kitab Al-Milal wa an-Nihal dijelaskan bahwa setiap orang yang keluar dari imam yang telah disepakati bersama dinamakan Kharijiy. ${ }^{20}$ Khawarij merupakan penyebutan atas suatu kelompok yang menolak arbitrase yang digunakan oleh Muawiyah dalam perang Shiffin. Khawarij menamakan diri mereka dengan sebutan kaum Syurah, yang berasal dari kata yasyri (menjual). Kata ini memiliki makna segolongan orang yang mengorbankan dirinya demi keridhaan Allah. ${ }^{21}$ Ada pula pendapat yang menyatakan bahwa Khawarij juga disebut sebagai Haruriyah. Ini dinukilkan dari kata 'Harura' yang merupakan nama sebuah tempat di kota Raqqah yang berlokasi di sekitar Kuffah. Sejarah menyebutkan bahwa tempat tersebut merupakan tempat berkumpul mereka yang telah memisahkan diri dari barisan Ali (pada waktu itu berjumlah sekitar 12.000 orang).

Khawarij dikenal sebagai aliran kalam tertua dalam sejarah peradaban Islam. Kelompok ini memiliki pandangan bahwa saat Ali menerima arbitrase yang diajukan oleh Muawiyah, maka ia telah melakukan dosa besar. Oleh karena itu, Ali dianggap kafir dan darahnya halal untuk dibunuh. Tak hanya Ali, semua orang yang mereka anggap telah melanggar ajaran Islam masuk ke dalam golongan kafir, termasuk diantaranya Muawiyah bin Abi Sufyan, Amr Ibn Al-'As, serta Abu Musa Al-Asy'ari. Landasan pengkafiran terhadap Ali dan beberapa kaum muslimin tersebut berpijak pada firman Allah yang berbunyi: wa man la yahkum bima anzalallahu faulaika humul kafirun. Barangsiapa yang tidak berhukum dengan apa yang diturunkan oleh Allah, maka mereka itulah orang-orang kafir.

Dalam rangka menegakkan agama Allah, Khawarij cukup teguh dan tegas menjalankan ideologinya. Kelompok ini dikenal sangat mudah menyerang sekte-sekte

19 Asy-Syahrastani, Al-Milal wa an-Nihal: Aliran-Aliran Teologi dalam Sejarah Umat Islam, terj. Asywadi Syukur (Surabaya: Bina Ilmu, tt), 124.

${ }^{20}$ Abu Al-Fath Asy-Syahrastani, al-Milal wa An-Nihal (Beirut: Dar al-Kutub al-Ilmiyyah), 150.

21 Sahilun A. Nasir, Pemikiran Kalam (Teologi Islam) Sejarah, Ajaran, dan Perkembangannya (Jakarta: PT Raja Grafindo Persada, 2010), 124. 
diluar mereka dan taat menjalankan nilai-nilai agama. ${ }^{22}$ Hal ini tak terlepas dari latar belakang mereka yang umumnya merupakan orang Arab Badawi. Kehidupan asalnya yang serba sederhana namun keras dan berani mempengaruhi mereka dalam melakukan penafsiran ayat yang cenderung tekstualis dan mengabaikan konteks.

\section{Murjiah}

Secara etimologis, Murjiah berasal dari padanan kata Bahasa Arab irja', yang bermakna menunda atau memberi pengharapan. ${ }^{23}$ Murjiah merupakan sekelompok masyarakat yang memiliki harapan besar akan ampunan Allah. Hal yang sama berlaku pada pelaku dosa besar. Sama seperti Khawarij dan Syiah, kehadiran aliran Murji'ah dimoderatori oleh persoalan politik yang berujung pada pertikaian sesama kaum muslimin.

Secara historis, peristiwa arbitrase memunculkan dua kelompok yang saling bertolak belakang, yakni aliran Syiah yang mendukung Ali dan Khawarij yang justru menentangnya. Pertikaian kedua kelompok ini semakin memanas manakala Ali wafat karena ditikam. Perselisihan berujung pada tuduhan saling mengkafirkan kubu lawan. Di tengah situasi politik yang tidak stabil tersebut, muncul sekelompok orang yang tidak ingin menentukan keberpihakannya kepada salah satu kubu yang bersengketa. ${ }^{24}$ Mereka inilah yang disebut sebagai kaum Murji'ah. Murjiah pada dasarnya memiliki kecenderungan politik terhadap Muawiyah pada permasalahan arbitrase. Akan tetapi pada praktiknya, aliran ini lebih bersifat netral dengan tidak menetapkan siapa yang salah dan yang benar pada perselisihan antara Syiah dan Khawarij. Mereka tidak ingin mendapat hujatan ketika harus memilih salah satunya sehingga aliran ini condong untuk tidak ikut campur atau memisahkan diri dari benang perselisihan tersebut.

Murji'ah memiliki prinsip bahwa penetapan kafir seseorang hendaknya dikembalikan kepada Allah. Baik golongan Ali maupun Muawiyah tetap dianggap sebagai orang mukmin karena mereka bersyahadat dan diyakini tidak melenceng dari jalan yang lurus. Adapun mengenai dosa besar yang dianggap telah dilakukan, penyelesaiannya ditunda hingga tiba hari perhitungan nanti saat Allah sendiri yang akan menghukumi mereka.

\section{Qadariyah}

Qadariyah berakar pada 'qadara' yang berarti memutuskan dan memiliki kekuatan atau kemampuan. Harun Nasution dalam tulisannya menyatakan bahwa Qadariyah ialah sebutan untuk kelompok yang menganggap bahwa semua orang memiliki kebebasan dalam menjalankan hidupnya. Semua perbuatan baik dan perbuatan buruk yang manusia lakukan pada dasarnya adalah atas kehendak dan kekuasaannya sendiri. Secara tidak langsung, aliran ini menafikan adanya peran takdir yang telah tertulis bagi setiap manusia sejak zaman azali ${ }^{25}$ dan meyakini bahwa hidup manusia tidak serta merta dipaksa untuk patuh pada apa yang telah ditakdirkan Allah.

Kemunculan aliran Qadariyah dipelopori oleh Ghilan ad-Dimasyqi, seorang pemuka aliran Murji'ah. Beberapa kalangan meyakini keberadaan aliran Qadariyah sebagai

${ }^{22}$ Muhammad Abu Zahrah, Tarikh al-Madzahib al-Fiqhiyyah wa al-Islamiyyah al-Mu'ashirah (Beirut: Daar al-Kutub al-Ilmiyyah, 1992), 57.

${ }^{23}$ Ummu Tamim, Menyingkap Aliran dan Paham Sesat, terj. Sufyan bin Zaidin Sinaga Abu Yazid (Jakarta: Pustaka Imam Ahmad, 2010), 127.

${ }^{24}$ Sariah, "Murji'ah dalam Perspektif Theologis," Jurnal Toleransi 4, 1 (2012): 70.

${ }^{25}$ Harun Nasution, Teologi Islam: Aliran-Aliran Sejarah Analisa Perbandingan, 35. 
siasat politik untuk melawaan kebijakan pemerintahan Bani Umayah yang dirasa telah melampaui batas. ${ }^{26}$

\section{Jabariyah}

Kata Jabariyah berasal dari 'Jabar' yang berarti memaksa. Aliran ini pertama kali dipelopori oleh Al-Ja'ad bin Dirham. Bertolak belakang dengan prinsip yang dipegang oleh Qadariyah, aliran Jabariyah meyakini bahwa sebagai seorang manusia, segala perbuatan baik dan buruk yang dilakukan telah ditakdirkan dan diciptakan oleh sang pencipta. Manusia sama sekali tidak memiliki daya, pilihan, dan kehendak sendiri. Dengan arti lain, segala perbuatan manusia timbul bukan karena kemauannya sendiri, namun perbuatan yang dipaksakan atas dirinya.

Pemahaman ini tersebar luas berkat kerja keras Jahm bin Safwan, seorang pemuka Jabariyah yang berasal dari Khurasan. ${ }^{27}$ Dikisahkan oleh Abu Zahrah, kehadiran aliran ini telah ada sejak zaman Bani Umayah menyatakan bahwa aliran ini telah tumbuh dan mulai menyebar sejak masa sahabat dan masa bani Umayyah. Kala itu berbagai persoalan mengenai qada dan qadar sering menjadi bahan diskusi oleh para tokoh agama.

\section{Mu'tazilah}

Mu'tazilah merupakan aliran teologi Islam tertua yang dibangun oleh Wasil bin Atha. ${ }^{28}$ Mu'tazilah secara etimologis berasal dari kata i'tazala dalam bahasa Arab yang memiliki arti memisahkan diri, menjauhkan diri, menyalahi pendapat orang lain. Mu'tazilah merupakan penyebutan bagi sekelompok orang yang memutuskan untuk memisahkan diri dari jamaah yang telah ada. Alasan pemisahan diri ini dilatarbelakangi oleh kekecewaan terhadap keputusan Hasan bin Ali bin Abi Thalib yang memberikan tampuk kekhalifahan kepada Muawiyah. ${ }^{29}$

Mu'tazilah memegang pengaruh kuat terhadap sejarah pengetahuan dan pemikiran Islam. Mu'tazilah lahir pertama kali di kota Basrah (saat ini dikenal dengan nama Irak), sebuah tempat yang menjadi pusat peradaban Islam di masa itu. Awal kemunculannya ditandai dengan banyaknya oknum muslim maupun nonmuslim yang berencana meruntuhkan kejayaan Islam melalui serangan-serangan pada segi aqidah. Salah satu kepercayaan yang menyimpang dari ajaran Islam namun berkembang pesat di Kufah dan Basrah adalah aliran Agnostik, yaitu sebuah prinsip yang mempercayai adanya Tuhan namun tidak mengimani ajaran agama apapun.

Dalam keadaan demikian, Mu'tazilah hadir sebagai wujud mempertahankan jati diri dengan mereduksi aliran menyimpang tersebut melalui metode pemikiran yang dikembangkan sedemikian rupa. Kaum Mu'tazilah dalam memberikan solusi atas sebuah problematika lebih banyak mempergunakan logika dan akal. Untuk itu, mereka dikenal dengan sebutan "kaum rasionalis Islam". Berdirinya Mu'tazilah juga sebagai upaya untuk membersihkan krisis kepercayaan terhadap umat Islam. Meskipun pada tahun-tahun selanjutnya Mu'tazilah mendapat kekuasaan politik dari al-Makmum untuk memaksakan pemikiran-pemikirannya kepada orang lain. ${ }^{30}$

\footnotetext{
${ }^{26}$ Sahilun A. Nasir, Pemikiran Kalam (Teologi Islam) Sejarah, Ajaran, dan Perkembangannya, 139.

${ }^{27}$ Harun Nasution, Teologi Islam: Aliran-Aliran Sejarah Analisa Perbandingan, 36.

${ }^{28}$ Abdul Aziz Dahlan, Teologi dan Aqidah dalam Islam (Padang: IAIN-IB Press, 2001), 75.

${ }^{29}$ Taufik Rahman, Tauhid Ilmu Kalam (Bandung: CV Pustaka Setia, 2013), 208.

${ }^{30}$ A. Hanafi, Pengantar Teologi Islam (Jakarta: Pustaka Al-Husna Baru, 2003), 72.
} 


\section{Asy'ariyah}

Nama Asy'ariyah dinisbatkan pada pelopor aliran ini, yaitu Abu al-Hasan alAsy'ari. Beliau merupakan salah seorang keturunan Abu Musa Al-Asy'ari yang cukup tajam menyelisihi pandangan Mu'tazilah. ${ }^{31}$ Pada mulanya, Al-Asy'ari yang merupakan anak tiri dari Al-Jubai menganut aliran Mu'tazilah sebelum akhirnya mencetuskan ideologi barunya. Para sejarawan meyakini beberapa asumsi terkait penyebab keluarnya Al-Asy'ari dari Mu'tazilah, salah satunya disebabkan oleh kelumpuhan Mu'tazilah dalam menjawab beberapa persoalan yang diajukan oleh Al-Asy'ari. Ajaran Asy'ariyah yang bercorak konvensional dengan mengedepankan al-Quran dan sunah di atas akal pikiran cukup berkembang pesat, terutama di wilayah Basrah.

Pada awalnya, Asy'ari merasa mendapatkan ilham dari Allah melalui sebuah mimpi. Didalam mimpi tersebut ia bertatapmuka langsung dengan Rasulullah. Sejak saat itu Asy'ari mulai memisahkan diri dari ajaran Mu'tazilah dan memperkokoh aqidahnya pada Al-Quran dan Sunnah. Mimpi tersebut merupakan jawaban dari permasalahan pelik yang belum ia dapati solusinya bahkan tidak dari gurunya sendiri, Al-Jubai. Seiring dengan kelemahan Mu'tazilah yang lambat laun membawanya pada kehancuran, Al-Asyari muncul sebagai sebuah aliran yang memiliki nilai-nilai pembaharuan sehingga mampu menarik massa cukup banyak dalam waktu yang relatif singkat.

\section{Maturidiyah}

Abu Mansur al-Maturidi merupakan pelopor dari aliran Maturidiyah. Aliran ini dilahirkan di wilayah Samarkand dengan dilatarbelakangi oleh beberapa faktor ${ }^{32}$, diantaranya ketidakpuasan sekelompok masyarakat terhadap ideologi Mu'tazilah yang dianggap berlebihan dalam memberikan otoritas pada akal. Di sisi lain, prinsip-prinsip ulama salaf juga tidak dapat diterima seutuhnya karena mengabaikan penggunaan logika. Faktor meluasnya ajaran Qaramithah yang dengan keras menentang ulama salaf juga membuat kekhawatiran yang cukup besar bagi kaum muslimin.

Untuk itu, Maturidiyah hadir dengan mengembangkan sebuah metode pemikiran melalui sinkronisasi dalil $\mathrm{Naql}$ dan 'Aql, dalam hal ini mempertemukan prinsip Mu'tazilah yang rasional dengan Hambali yang tradisional. Sebagian ulama lain memandang titik temu Mu'tazilah dan Ahl al-Hadits ada pada golongan Asy'ariyah, sedangkan titik temu antara Asy'ariyah dan Mu'tazilah didapatkan di golongan Maturidiyah. ${ }^{33}$ Namun pada prakteknya, Maturidiyah lebih banyak memberikan porsi pada akal jika dibandingkan dengan Asy'ariyah.

\section{E. Kesimpulan}

Sejarah mencatat kehadiran sekte-sekte keislaman pada mulanya tidak muncul sebagai sebuah aliran teologi sebagaimana pengklasifikasian yang diberikan di buku-buku agama dewasa ini. Sektarianisme dalam Islam lahir sebagai akibat dari gejolak politik yang tidak saling mendukung satu sama lain dalam tubuh kaum muslimin. Kelompok-kelompok ini yang pada awalnya berafiliasi ke politik lambat laun bertransformasi menjadi aliran

31 Al-Imam Muhammad Abu Zahrah, Taarikh al-Madzahib al-Islamiyah fi as-Siyasah wa al'Aqaaidi wa at-Tarikh al-Madzahib al-Fiqhiyah (Kairo: Daar al-Fikr Al-Arabiy, 1996), 163.

${ }^{32}$ Hamka, "Maturidiyah: Kelahiran dan Perkembangannya," Jurnal Hunafa 4, 3 (2007): 261.

${ }^{33}$ Muhammad Abu Zahrah, Tarikh al-Madzahib al-Fiqhiyyah wa al-Islamiyyah al-Mu'ashirah, 167. 
teologi demi menancapkan ideologinya ke berbagai sendi masyarakat. Perpecahan berbalut perbedaan pemahamanpun menjadi sumbu konflik yang hingga kini belum berhenti, khususnya di kawasan Timur Tengah sebagai rahim lahirnya sekte-sekte keislaman. Jika ditelusuri lebih jauh, munculnya sektarianisme dalam Islam tidak terlepas dari fungsi Nabi Muhammad yang tidak hanya sebagai Nabi dan Rasul, tetapi juga kepala negara. Ketika beliau wafat, persoalan politik mengenai pengganti Nabi sebagai kepala negara menjadi hal krusial dikalangan umat, disamping posisinya sebagai Nabi dan Rasul yang memang tidak bisa tergantikan. Maka pada kasus ini ijtihadpun memainkan peranan penting meski pada akhirnya tidak berhasil merangkul seluruh suara kaum muslimin, bahkan hingga pada periode beberapa khalifah berikutnya. Seiring berjalannya waktu, keberagaman suara dalam kekhalifahan memunculkan kubu-kubu yang terus menyebarluaskan pengaruhnya ke seluruh penjuru negeri membentuk sekte-sekte keagamaan yang saling bertolak belakang satu sama lain. Beberapa dari sekte tersebut masih dapat kita temukan di masa sekarang.

\section{DAFTAR PUSTAKA}

Abidin, Zainal. "Syiah dan Sunni dalam Perspektif Pemikiran Islam.” Jurnal Hunafa 3, 2 (2006).

Al-Asy'ari, Abu Hasan. Maqallat al-Islamiyyin wa Ikhtilafu al-Mushallin. Kairo: Maktabah An-Nahdhah al-Misriyyah, 1969.

Asy-Syahrastani. Al-Milal wa an-Nihal: Aliran-Aliran Teologi dalam Sejarah Umat Islam, terj. Asywadi Syukur. Surabaya: Bina Ilmu, tt.

Azra, Azyumardi. Transformasi Politik Islam: Radikalisme, Khilafatisme, dan Demokrasi. Jakarta: Prenadamedia Group, 2016.

Dahlan, Abdul Aziz. Teologi dan Aqidah dalam Islam. Padang: IAIN-IB Press, 2001.

Dzujali, A. Fiqh as-Siyasah: Implementasi Kemaslahatan Umat Islam dalam RambuRambu Syariah. Jakarta: Kencana, 2013.

Hakim, Abdul. "Konflik Sektarian Dan Perkembangan Pemikiran Dalam Islam." SAFINA: Jurnal Pendidikan Agama Islam 1, 1 (2016).

Hamka. "Maturidiyah: Kelahiran dan Perkembangannya." Jurnal Hunafa 4, 3 (2007).

Hamur, Ahmad Ibrahim. Shadrat min Tarikh al-Daulah al-Umawiyah fi al-Sharq. Kairo: Daar al-Tiba'ah al-Muhammadiyah, 1998.

Hanafi, A. Pengantar Teologi Islam. Jakarta: Pustaka Al-Husna Baru, 2003.

Hasyimi, A. Sejarah Kebudayaan Islam. Jakarta: Bulan Bintang, 1973.

Hitti, Philip K. History of The Arabs. London: Macmillan Press, 1970.

Machasin. Islam Dinamis Islam Harmonis, Lokalitas, Pluralisme, dan Terorisme. Yogyakarta: LKIS, 2017.

Munawir, Ahmad Warson. Kamus Munawir Arab-Indonesia Terlengkap. Surabaya: Pustaka Progresif, 2007.

Nasir, Sahilun A. Pemikiran Kalam (Teologi Islam) Sejarah, Ajaran, dan Perkembangannya. Jakarta: PT Raja Grafindo Persada, 2010.

Nasution, Harun. Teologi Islam: Aliran-Aliran Sejarah Analisa Perbandingan. Jakarta: UIPress, 1986.

Nasution, M. Syamruddin. Arbitrase Menjadi Penyebab Timbulnya Sekte-sekte dalam 
Islam. Pekan Baru: Yayasan Pusaka Riau, 2011.

Purnama, Fahmi Farid. "Khawarijisme: Pergulatan Politik Sektarian dalam Bingkai Wacana Agama." Jurnal Al-A'raf Pemikiran Islam dan Filsafat 3, 2 (2016).

Rahman, Sainul. "Tensi Sektarianisme dan Tantangan Demokrasi di Timur Tengah Pasca Arab Spring: Kasus Tunisia dan Yaman.” Jurnal ICEMS 3, 1 (2019).

Rahman, Taufik. Tauhid Ilmu Kalam. Bandung: CV Pustaka Setia, 2013.a

Sahidin, Ahmad. "Memahami Sunni dan Syiah: Sejarah, Politik, dan Ikhtilaf." Jurnal Maarif 10, 2 (2015)

Sariah. "Murji'ah dalam Perspektif Theologis." Jurnal Toleransi 4, 1 (2012).

Syalabi, Ahmad. Tarikh al-Islam wa al-Hadharah al-Islamiyah. Mesir: Maktabah alNahdhah al-Misriyah, 1975.

Tamim, Ummu. Menyingkap Aliran dan Paham Sesat, terj. Sufyan bin Zaidin Sinaga Abu Yazid. Jakarta: Pustaka Imam Ahmad, 2010.

Zahrah, Imam Muhammad Abu. Aliran Politik dan Aqidah dalam Islam, terj. Abd. Rahman Dahlan dan Ahmad Qarib. Jakarta: Logos Publishing House, 1996.

Zahrah, Muhammad Abu. Tarikh al-Madzahib al-Fiqhiyyah wa al-Islamiyyah alMu'ashirah. Beirut: Daar al-Kutub al-Ilmiyyah, 1992.

Zahrah, Muhammad Abu. Taarikh al-Madzahib al-Islamiyah fi as-Siyasah wa al- 'Aqaaidi wa at-Tarikh al-Madzahib al-Fiqhiyah. Kairo: Daar al-Fikr Al-Arabiy, 1996. 